\title{
Life cycles and growth rates of two morphotypes of Cystodytes (Ascidiacea) in the western Mediterranean
}

\author{
Susanna López-Legentil ${ }^{1,2, *}$, Markus Ruchty ${ }^{3}$, Arnau Domenech ${ }^{1}$, Xavier Turon ${ }^{1}$ \\ ${ }^{1}$ Department of Animal Biology (Invertebrates), Faculty of Biology, University of Barcelona, 645, Avinguda Diagonal, \\ 08028 Barcelona, Spain \\ ${ }^{2}$ Laboratoire de Chimie des Biomolécules et de l'Environnement (Centre de Phytopharmacie), University of Perpignan, \\ 52, Avenue Paul Alduy, 66860 Perpignan, France \\ ${ }^{3}$ Department of Behavioral Physiology and Sociobiology, University of Würzburg, 97074 Würzburg, Germany
}

\begin{abstract}
The reproductive cycles, growth and survival of the 2 most abundant color morphs (blue and purple) of the colonial ascidian Cystodytes occurring in the western Mediterranean were studied over a period of 20 mo. Previous reports have assigned the 2 morphotypes to the nominal species C. dellechiajei. A seasonal pattern emerged, in which larval release occurred in late spring and summer, followed by a period of active growth. Significant differences between morphotypes were also detected: the cycles of both reproduction and growth rates of the purple morph lagged 1 to 2 mo behind those of the blue morph. Within morphotypes, the time course of reproductive activity and growth rates also displayed a temporal lag that suggests partitioning of resources to either reproduction or growth. In particular, the growth rates of the 2 morphotypes peaked when reproductive activity was at its lowest. There were no significant differences in mortality between these forms, and in both cases a significant negative correlation was found between mortality and size. In the blue morph, maximal growth rate was negatively correlated with size, whilst no significant relationship between growth rate and size was detected in the purple morph. There were no significant differences in growth between colonies of the purple morph that were in contact with the toxic sponge Crambe crambe and those that were not. The differences found in the reproductive cycles of these 2 morphotypes match previously reported genetic and chemical divergences.
\end{abstract}

KEY WORDS: Life cycles · Growth rates · Ascidians · Cystodytes · Reproduction · Mortality · Invertebrates

\section{INTRODUCTION}

In modular marine invertebrates the interaction between genotype and environment often generates a distinct profile of growth, fission, fusion, regeneration and senescence for each clone (reviewed in Larwood \& Rosen 1979, Jackson et al. 1985, Harper et al. 1986, Karlson 2002). Thus, the study of biological cycles in colonial ascidians, including growth, reproduction and mortality, often reveals complex patterns (Bak et al. 1981, Ryland et al. 1984, Grosberg 1988, Turon \& Becerro 1992). In colonial ascidians, fusion and fission phenomena may occur frequently and cause rapid changes in original colony size (Mukai \& Watanabe 1974, Bak et al. 1981, Stocker 1991, Stocker \& Underwood 1991). On the other hand, environmental parameters, such as habitat boundaries, competition and partial predation, may cause a decrease in growth rate with size (Brunetti \& Copello 1978, Brunetti et al. 1988, Stocker \& Underwood 1991, Turon \& Becerro 1992). For instance, Stocker \& Underwood (1991) found that sexual and asexual reproduction rates of Didemnum moseleyi (Didemnidae) were lower in specimens found close to sponges. Due to the influence of such intricate and heterogeneous factors on life cycles, organisms of the same age can vary widely in their growth, survival 
and fecundity parameters. Therefore, accurate measurements of relevant life-history traits can only be obtained by following the fates of individual colonies over as much of their life cycle as possible (Hughes \& Cancino 1985, Stocker 1991). Such important biological information is scarce for modular benthic invertebrates (Jackson \& Coates 1986, Turon et al. 1998) and, in particular, for colonial ascidians (Bak et al. 1981, Grosberg 1988, Turon \& Becerro 1992, Yund et al. 1997), hindering the development of demographic and life-history theories applicable to clonal organisms (Caswell 1982, 1985, Williams 1986, Sebens 1987, Okamura et al. 2002).

Temperate seas display marked seasonal fluctuations in environmental parameters that are reflected in the life-cycle patterns of marine invertebrates (Osman 1977, Sutherland \& Karlson 1977, Sebens 1986, reviewed in Coma et al. 2000). Seasonality has commonly been linked to temperature, but other factors, such as nutrient availability, should also be considered (Coma \& Ribes 2003). To date, water-temperature changes (Berrill 1935, Millar 1971, Turon \& Becerro 1992, Durante \& Sebens 1994) and/or what Berrill (1935) called 'sexual exhaustion' (when larval brooding has drained nutritive reserves) have been used to explain the continued alternation between phases of maximum asexual and sexual reproduction observed in many ascidians (Millar 1952, 1971, 1974, Morgan 1977, Brunetti et al. 1988, Durante \& Sebens 1994). This trade-off suggests a partitioning of energy resources in the colony over the course of its life cycle that may be used alternatively for reproduction and growth. Nevertheless, few studies have addressed the existence of trade-offs in resource allocation in colonial ascidians (Yund et al. 1997, Newlon et al. 2003, Tarjuelo \& Turon 2004). In the Mediterranean, high water temperatures in summer may also induce dormancy and aestivation phenomena in some invertebrates (Coma et al. 2000). In ascidians, aestivation has been observed in Clavelina lepadiformis (Clavelinidae) (De Caralt et al. 2002), while non-feeding, resting forms have been reported in Pseudodistoma crucigaster (Pseudodistomidae), Polysyncraton lacazei (Didemnidae) (Turon 1988, 1992, Turon \& Becerro 1992) and Botrylloides leachi (Styelidae) (Brunetti 1976).

Previous reports of Cystodytes (Aplousobranchiata, Polycitoridae) in the Mediterranean have been routinely attributed to the nominal species C. dellechiajei (Della Valle, 1877) (Pérès 1958, Turon 1987, Brunetti 1994). This colonial species is widely distributed in both tropical and temperate waters. In the Mediterranean, even though zooid anatomy is remarkably uniform, the general colony morphology of C. dellechiajei varies greatly, especially in terms of color and spicular composition. Different variants can occur sympatrically at the same locality. This has led some authors to suggest that there may in fact be several species (Turon 1987, Brunetti 1994, Méliane 2002). López-Legentil \& Turon (2005), studying specimens attributable to this species from the western Mediterranean, found noticeable genetic variability, and up to 5 clades were substantiated using mtDNA sequences. The 2 most abundant color morphs found (purple and blue) appeared to be clearly separated in 2 of these 5 clades. In addition, López-Legentil et al. (in press) have found chemical differences in alkaloid composition between the purple and the blue morphs. These studies concluded that data on gene flow and biological cycles were necessary to determine whether these morphotypes correspond to separate species.

The aims of the present work were (1) to compare the reproductive traits, growth and survival of the 2 most abundant morphotypes of the genus Cystodytes occurring in the western Mediterranean (purple and blue); (2) to correlate these biological traits with other parameters, such as colony size, water temperature and the presence or absence of nearby competitors; and (3) to contribute biological information to the issue of the taxonomic status of chromatic varieties in this genus.

\section{MATERIALS AND METHODS}

Sample collection and assessment of biological cycles. As preliminary surveys did not reveal any locality in which the 2 morphs were abundant enough to sustain prolonged sampling, we monitored a population of the blue morph and a population of the purple morph of Cystodytes occurring in 2 different localities of the same stretch of coast in the NE of Spain (Palamós and L'Escala, respectively; Fig. 1).

The specimens were attributable to Cystodytes dellechiajei, based on Turon (1987) and Kott (1990). Morphologically, the only apparent differences between the 2 morphotypes were their color and the presence of small, spherical spicules (in addition to the large, discshaped spicules characteristic of the genus) in the purple morph (López-Legentil \& Turon 2005). Both populations were sampled monthly from July 2002 to January 2004. At each locality and on each sampling date, 10 colonies (separated from each other by at least $2 \mathrm{~m}$ ) were collected by SCUBA diving and immediately fixed in $5 \%$ formaldehyde. Water temperature was also recorded on each sampling date. Whenever possible, the 2 sites were sampled the same day, or, when this was not possible, with a minimum delay between sampling operations. Once in the laboratory, the colonies were dissected and at least 10 zooids per colony were observed; the reproductive state of each zooid 


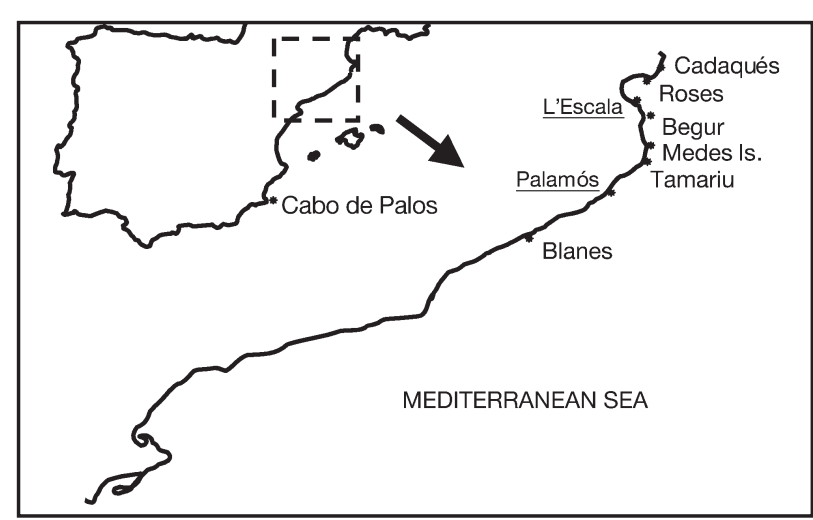

Fig. 1. Map of Spain with the position of the localities studied. The 2 locations at which most of the monitoring was conducted (L'Escala and Palamós) are underlined

was then visually assessed under a stereomicroscope. Cystodytes is hermaphrodite and protandric; therefore, the state of each zooid was scored according to one of the following categories: (1) immature colonies, (2) presence of testes, (3) presence of testes with a sperm duct filled with sperm, (4) presence of oocytes, (5) brooding embryos or (6) brooding mature larvae. Clearly, these categories (with the exception of the first) were not mutually exclusive. When a zooid could be scored in $>1$ category, we scored the highest. A maturity index (MI) was then calculated for each colony by averaging the category number of the zooids examined. Monthly means were then calculated from the values of the 10 colonies studied.

As we monitored different sites for each morphotype, we performed additional samplings at the Medes Islands archipelago, which is located between the other 2 localities (Fig. 1). At this locality both morphotypes coexisted, although the blue population was scarce and could not sustain prolonged sampling. We therefore sampled this site on a seasonal basis (4 times $\mathrm{yr}^{-1}$ ) during the same period as the main localities. In addition, we occasionally surveyed other populations distributed along the Spanish Mediterranean coast: Blanes, Tamariu and Cabo de Palos for the blue morph, and Cadaqués, Roses and Begur for the purple morph (Fig. 1). Furthermore, from July to September 2004, we repeated the sampling in Palamós and L'Escala, to verify that the pattern found in $2002 / 2003$ was consistent between years.

Estimation of growth rates. Growth of the blue and purple colonies was monitored at Palamós and L'Escala, respectively, by means of a digital photographic study of marked individuals from September 2002 to January 2004. At both localities, walls of similar inclination, orientation and depth were selected. The monitored colonies were mapped using nails driven into the rock and underwater sketches and measurements. As this species displays an encrusting form, changes in the surface area of the colonies provided a good estimate of growth. Colony outlines were added digitally to the pictures, and areas were then measured using the SigmaScan Pro 5 program (Jandel). Fusions and divisions were also recorded. When fusion occurred, the areas of the colonies before merging were added together to give a single value per survey. When fission occurred, the areas of the resulting clone-mates were summed in subsequent measurements. Mortality of colonies was also recorded. We monitored 42 colonies of the blue morph and 39 of the purple form (each of them with their own history of fissions and fusions, so the actual number of colonies varied from date to date).

From changes in area over time, a monthly growth rate (GR) was calculated using the formula:

$$
\mathrm{GR}_{m}=\frac{\left(A_{m}-A_{m-1}\right)}{A_{m-1}}
$$

where $A_{m}$ and $A_{m-1}$ are the areas at month $m$ and at the previous month $(m-1)$, respectively. This growth rate represents the change in area over 1 mo. The monthly growth rates of each colony presented here have been smoothed using a weighted moving average [(current value $\times 0.5)+($ previous value $\times 0.25)+$ (subsequent value $\times 0.25$ )] to avoid noisy fluctuations.

Data treatment. A 2-way ANOVA with morphotype and month as main factors was used to ascertain differences between the maturity indexes. For the comparison of growth rates, a non-parametric repeatedmeasures analysis of variance (ANOVAR) using a randomization procedure based on Manly (2001) was performed. This consists of a 2-stage permutation of the data: first, individuals were randomly reassigned to the 2 color morphs, and then readings for each individual were randomly rearranged among the observation times. The whole data series was randomized 4999 times (plus the observed one) to approximate the null hypothesis distribution of the sum of squares for each factor and their interaction. Finally, we examined how extreme the observed values were in the distribution generated. An effect was judged significant when the observed sum of squares was exceeded by $<5 \%$ of the corresponding values in the randomization series. The entire data set could be used, including colonies that died during monitoring. For these, the permutation between times was carried out only within the period in which the colony was present in the study.

Survival of colonies was analyzed using the life table method (Krebs 1989), and hazard functions were computed for both localities. Survival of the 2 morphotypes was compared using a Wilcoxon-type test (Fox 1993). Cox's proportional hazards model (Fox 1993) was run 
to assess whether a relationship existed between survival time and maximal and final size of the colonies.

Spearman rank correlations were used to assess the relationship between size (mean of the study period) and mean and maximal growth rate of the colonies. Cross-correlation analyses (using the Pearson coefficient) were used to compare the cycles of reproduction and growth at both localities, as well as to assess relationships between these cycles and temperature.

Finally, we observed frequent contacts between some colonies of the purple morph and the abundant toxic sponge Crambe crambe (Becerro et al. 1995). To determine whether the growth rates of these colonies were affected by the presence of this competitor, we performed a Mann-Whitney test on the average growth rate of colonies surrounded or not by this sponge.

The packages Systat version 9.0, Statistica version 4.0 and Sigmastat version 2.0 were used for analyses. The randomization routine was written in Turbopascal version 6.0 by X.T.

\section{RESULTS}

\section{Reproduction}

The time course of the main reproductive categories considered of Cystodytes spp. is shown in Fig. 2 as the percentage of zooids in each state considered. A seasonal reproduction is clearly substantiated for both populations, although there are also important temporal differences. Zooids with gonads were present throughout the year, but the sequence of reproductive stages exhibited a clear temporal trend. The reproductive state was markedly uniform within colonies. In most cases only a single or 2 different reproductive categories were observed within a given colony. Some between-colony variation was found, but in general the reproductive state of the colonies was similar at any given date.

In the blue morph, immature zooids were only observed (although in small percentages) in summer, with testes, oocytes and embryos appearing sequentially from summer to mid-spring (Fig. 2). Mature larvae were found in June, and the cycle was almost over (with only a few larvae remaining) in July. In the purple morph, immature zooids were more abundant $(\sim 40 \%)$ at the end of summer, followed by the sequential appearance of testes, oocytes and embryos (Fig. 2). Well-developed larvae were found in July through September, when the cycle restarted. Larval release, therefore, seemed to take place at the end of June in the blue form and from the end of July to September in the purple morph. The difference appears to be due to a longer period of oocyte vitellogenesis in the latter (6 mo) than in the former (4 mo).

The evolution of the maturity index (MI) over time is shown in Fig. 3. Reflecting the temporal lag detected, the MI increased earlier in the blue population (from September onwards) and reached a peak in June, 2 mo before the highest sea temperatures occurred, followed by an abrupt decrease as larval release proceeded. In contrast, for the purple population, the MI increased in winter and the breeding season occurred in late spring and summer, reaching a peak in July. Larval release occurred 1 mo before the water temperature reached its maximum (Figs. $2 \& 3$ ). Although the study began in July 2002, the same lag seemed to occur in 2002 (from July to September the MI increased in the blue morph and decreased in the purple morph), and examination of the samples from July, August and September 2004 (not shown) yielded exactly the same pattern as in the corresponding months of 2003. The maturity indices measured at the Medes Islands locality, where the 2 morphotypes coexist, showed the same temporal trend as observed in L'Escala and Palamós (Fig. 3). Although we have less temporal precision due to the seasonal nature of the sampling, the MI increase in the blue morph occurred earlier than in the purple form. By late spring, the MI index was higher for the blue morph, whilst by midAugust the MI had dropped in the blue population and was maximal in the purple morph. As for other localities (Fig. 3), these observations were consistent with the cycles observed in the monitored populations, again indicating that the temporal lag between the 2 morphotypes is a general feature in the area studied.

The 2-way ANOVA on MI revealed that morphotype, time and the interaction between the 2 were significant ( $p<0.001$ in each case), indicating a different time course of the reproductive cycle at both localities. Moreover, cross-correlation analyses of the evolution of MI showed that the reproductive cycle of the purple morph lagged 1 to 2 mo behind that of the blue one, as indicated by a significant correlation at these time intervals (Fig. 4).

The cross-correlation analyses also showed significant positive correlations between the maturity index and the temperature measured in the third and fourth subsequent months for the blue population and in the first and second subsequent months for the purple morph (Fig. 4). This result reflects the fact that the course of the MI was some months advanced with respect to temperature in the blue population, while this advancement was less marked in the purple morph.

A resting or non-feeding state occurred in June 2003 in the majority of blue colonies. This phenomenon was very brief and did not last for more than a few weeks: at the next observation time, the colonies were active 

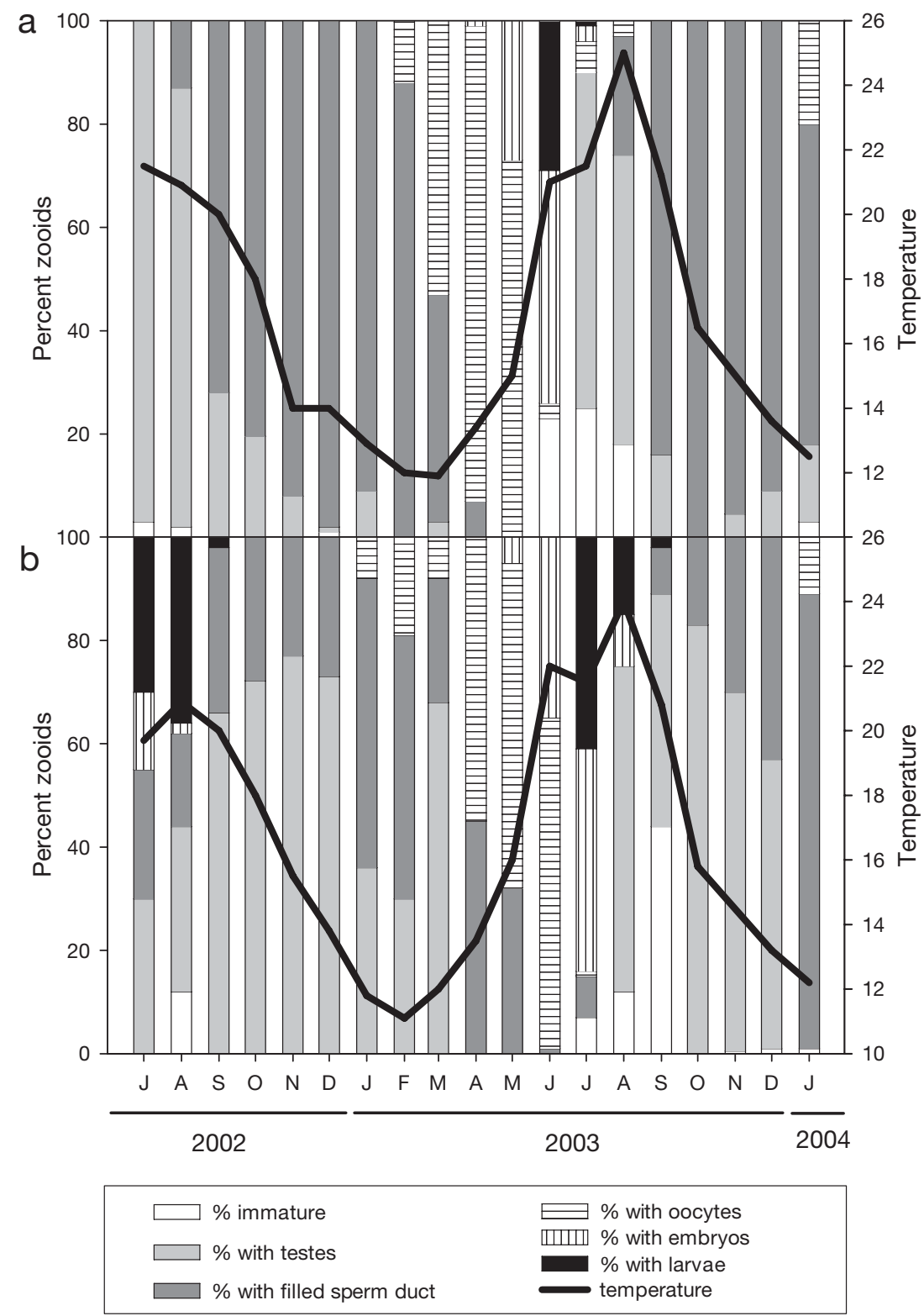

Fig. 2. Cystodytes spp. Reproductive cycles in the (a) blue and (b) purple populations indicated as percentage of zooids (mean of 10 colonies) in the different states considered. Temperature values are superimposed vated sea temperatures, while in winter the growth was restricted, or even negative. A lag similar to the one observed for the reproductive cycle was also evident in the growth rates, with peak values in the purple morph being reached 1 mo later (August) than in the blue morph (July). Interannual differences were also observed. For the blue morph, GRs were lower during the second than the first autumn surveyed, while the reverse was true for the purple morph. Overall growth during the study period was higher for the purple population: the initial and final colony sizes for the blue morph were $537 \pm$ 87 and $624 \pm 114 \mathrm{~mm}^{2}$, respectively (mean $\pm \mathrm{SE}$ ), while the purple morph displayed values of $551 \pm 89$ and $901 \pm 140 \mathrm{~mm}^{2}$, respectively.

The results of the repeated-measures ANOVA using the randomization test on the monthly GR showed that time, morphotype and the interaction between the 2 were significant $(p<0.001, p=0.046$ and $\mathrm{p}<0.001$, respectively). The significant interaction term indicates that the time course of growth was different for the blue and purple colonies. The growth cycles of both morphs followed the same general pattern, but were shifted by approximately 1 mo. Accordingly, a cross-correlation analysis comparing the 2 morphotypes showed the highest positive correlation between GRs at a 1 mo lag (Fig. 5). Crosscorrelation analyses also indicated that monthly growth rates and temperature covaried positively over time for both morphotypes (Fig. 5).

There were no significant differences in mortality between the 2 morphotypes considered (Gehan's Wilcoxon test $\mathrm{p}=0.98$ ). By the end of the study, $30(71 \%)$ colonies of the blue morph and $30(77 \%)$ of the again. The affected colonies were covered with a glassy cuticle that sometimes formed a reticulated net over the surface, and no siphonal aperture was visible. This phenomenon occurred when the MI was maximal. No similar state was observed in the purple form.

\section{Growth rates and mortality}

The mean growth rates (GR) are also depicted in Fig. 3. The periods of growth fluctuated seasonally. The highest GRs were obtained during periods of ele- purple form survived. No temporal trend was apparent in the plot of the hazard function with time (not shown). In addition, Cox's regression model between hazard rate and maximal and final colony size reached, exhibited a significant negative correlation between mortality and size for both morphotypes $(p<0.001$ in all cases). Dead individuals often corresponded to colonies $<100 \mathrm{~mm}^{2}$ in surface area, and no mortality occurred in individuals of sizes $>500 \mathrm{~mm}^{2}$.

In terms of the relationship between size and GR, in all cases the Spearman correlation coefficient was negative, indicating a tendency towards less growth in 


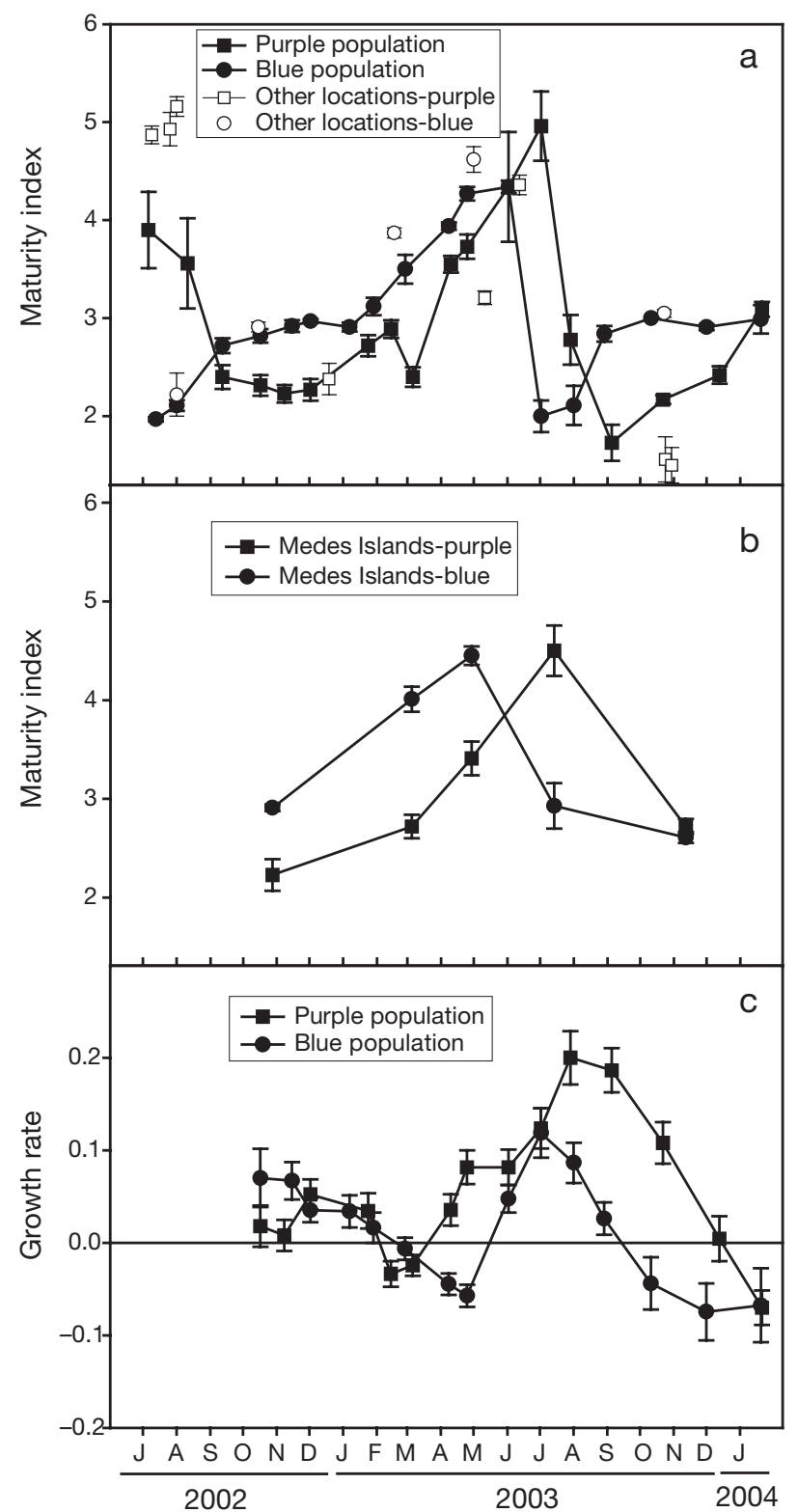

Fig. 3. Cystodytes spp. (a) Time course of the maturity index in Palamós (blue population) and L'Escala (purple population). Open circles and squares indicate the maturity index found in other localities inhabited by the blue and purple morphotypes, respectively. (b) Seasonal time course of the maturity index of both morphotypes at 1 locality in which they co-occur (the Medes Islands). (c) Mean growth rates obtained for the monitored colonies of the blue and purple morphotypes

larger specimens, but the relationship was only significant between size and maximal growth rate in the blue morph $\left(\mathrm{r}_{\mathrm{s}}=-0.392, \mathrm{p}=0.01\right)$. The comparison of size and mean growth rate in the blue form, or between size and mean and maximal growth rate in the purple morph, yielded non-significant correlation

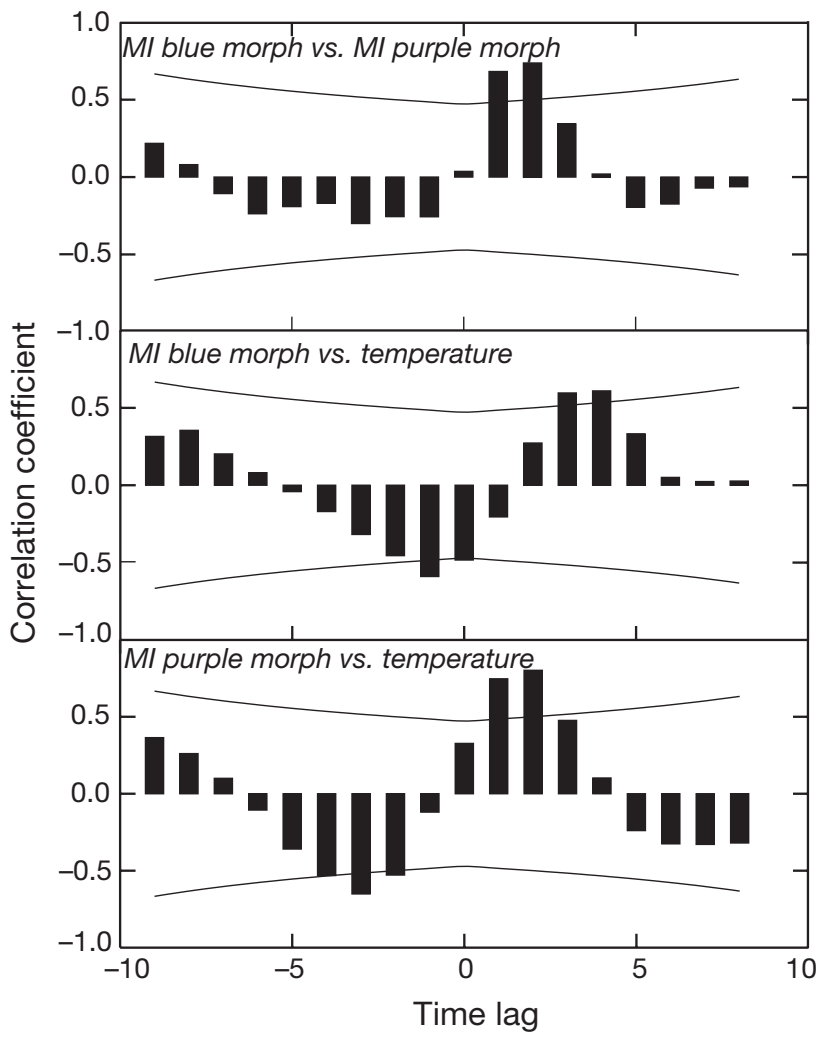

Fig. 4. Cystodytes spp. Cross-correlation analyses of the maturity indices (MI) of the blue and purple morphotypes, between them and with the temperature. Time lag is in months

values ( $p>0.6$ in all cases). The Mann-Whitney test showed no significant differences between growth rates of purple colonies surrounded by the toxic sponge Crambe crambe and those of colonies that were not $(p=0.801)$.

For both morphotypes, cross-correlation analyses (Fig. 6) showed a lag between maturity indices and growth rates. The lag was greater for the blue morph, and significant positive correlations were found between MI and GR in the third subsequent month, while in the purple morph significant positive relationships existed at lags of 1 to $3 \mathrm{mo}$. At time lag 0 , the usual Pearson correlation showed a significant negative correlation for the blue morph and a positive, but small and non-significant, one for the purple form (Fig. 6).

Fusions and fissions occurred randomly in both populations, with no clear temporal pattern. A total of 9 fusion and 23 fission events were recorded during the monitoring of the 42 colonies of the blue morph, while 13 fusions and 20 fissions were observed in the 39 colonies of the purple population; $73.6 \%$ of the colonies of the blue morph and $76.1 \%$ of the colonies of the purple morph experienced at least 1 fusion or fission event. 


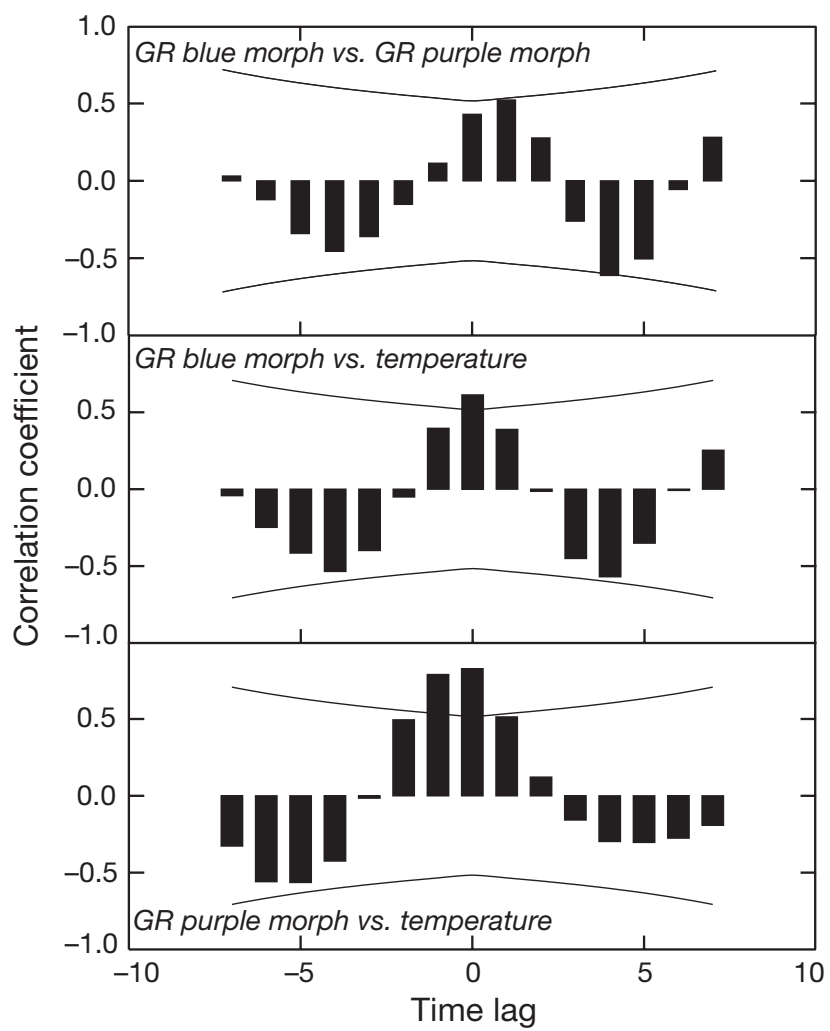

Fig. 5. Cystodytes spp. Cross-correlation analyses of the growth rates (GR) of the blue and purple morphotypes, between them and with the temperature. Time lag is in months

\section{DISCUSSION}

Both morphotypes showed a clear seasonal cycle for reproduction and growth. Larval release occurred in late spring and summer, followed by a period of asexual growth. Moreover, the present study revealed significant differences in growth rates and reproductive cycles between the blue and purple morphs, currently considered to belong to the species Cystodytes dellechiajei. The purple population lagged 1 to 2 mo behind the blue one in the time course of both parameters, and the pattern was consistent between years. Although the 2 populations studied were found along the same stretch of coast and they inhabited the same type of community, it may be argued that the differences observed were the result of local conditions. Indeed, differences in reproductive allocation patterns often arise from genetic differences, from environmental influences, or from interactions of these 2 factors (Forbes 2002). However, the same lag in the reproductive cycle was observed at the Medes Islands, where specimens of the 2 morphotypes are found side by side, under exactly the same environmental conditions. In addition, sampling of other populations showed that the biological cycles were highly coherent within color

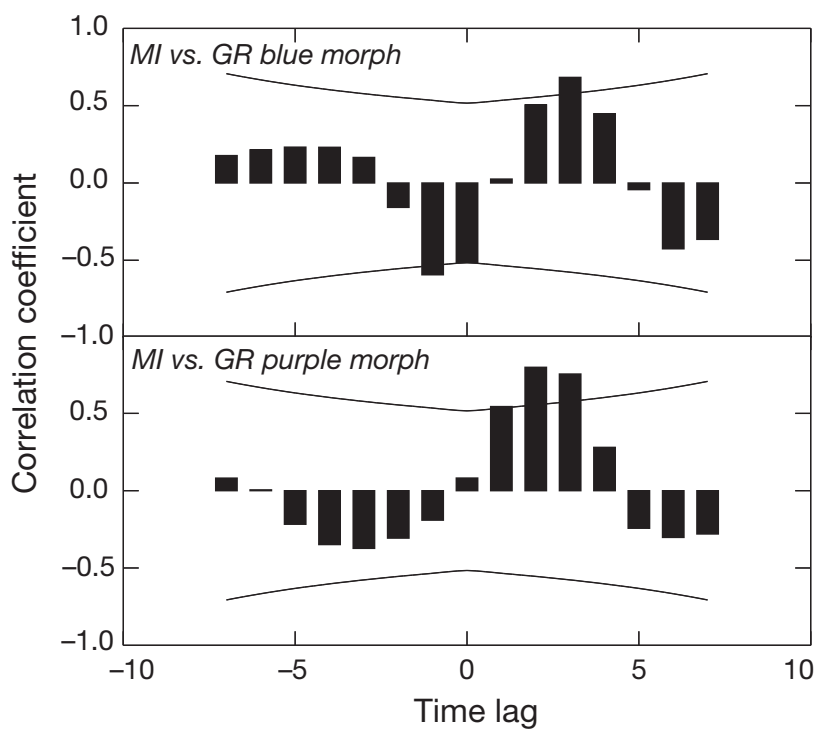

Fig. 6. Cystodytes spp. Cross-correlation analyses between the maturity indices (MI) and the growth rates (GR) in the 2 morphotypes. Time lag is in months

varieties. Taken together, and although an effect of local environmental conditions cannot be disregarded, the evidence indicates that the pattern found is more likely to be the result of genetically fixed differences between these morphotypes.

There were no differences in the mortality observed between morphotypes, and a clear negative relationship with size was observed. Fragmentation and reduction in size usually preceded the death of colonies. Similar patterns of reduced mortality with size have been reported for ascidians and other invertebrates (Turon \& Becerro 1992, Turon et al. 1998), indicating that upon reaching a certain threshold size mortality is reduced in modular organisms (escape in size: Sebens 1982). In our case, a bigger size may represent a better ability to compete for space, or the possibility of surviving bulldozing by sea urchins or fish attacks (we observed occasional instances of both).

Modular organisms often present a high inter-individual variability in growth rates (Ayling 1983, Todd \& Turner 1988, Garrabou \& Zabala 2001, Tanaka 2002). In our study, some colonies remained small throughout the study period, while others exhibited marked changes in size. In addition, fusions and fissions were not rare. In both morphotypes, fission was the most frequent phenomenon, with no clear temporal pattern. Fusion is generally restricted to colonies of close kin in invertebrates (Hughes 2002), while fission, if frequent, may lead to metapopulation structure (Okamura et al. 2002). In our case, fusions mainly occurred between recently separated clone-mates, as described in another ascidian species by Stocker (1991). Neverthe- 
less, the fragment dynamics of this species is much lower than that reported for other colonial ascidians, such as some Didemnidae (Ryland et al. 1984, Stocker \& Underwood 1991).

In the blue morph, a significant negative effect of size on maximal growth rates was evident, indicating less scope for growth once a certain area has been reached. This observation is in agreement with previous results in ascidians and other encrusting invertebrates (Turon \& Becerro 1992, Garrabou \& Zabala 2001). However, the same relationship was not significant in the purple morph, suggesting that this effect is unlikely to be due to space saturation and that it may represent an intrinsic characteristic of the blue morphotype.

In the Mediterranean, a variety of biological strategies for colonial ascidians regarding the duration and seasonality of reproductive periods have been described (see Turon 1988, Turon \& Becerro 1992, Tarjuelo 2001, De Caralt et al. 2002, Molin et al. 2003). Many species reproduce in spring and early summer (Turon 1988), as also seen in this study. On the other hand, food availability may underlie the seasonal patterns, as a summer energy shortage has been described in Mediterranean littoral systems (Coma \& Ribes 2003). In our case, larval release took place before maximal temperatures were reached, which indicates that reproductive investment is made mainly before that summer shortage. However, growth rates are maximal during the summer months, so they are not constrained by this limited food availability. Seasonal patterns can also be shaped by the trade-off between resource allocation to reproduction and growth. In our study, the peak growth rate always occurred after reproduction was over, which may indicate a partitioning of the energy resources of the colony over the course of its annual cycle (Yund et al. 1997). In Cystodytes, investment in reproduction is very high, as the weight of larvae produced by a single zooid is almost equal to the weight of the zooid itself (Tarjuelo \& Turon 2004). Investment in reproduction may be, therefore, the parameter that drives the cycles, while allocation to growth may be cheaper in energetic terms.

Turon $(1988,1992)$ described a non-feeding state with regression of thoraces and the appearance of a glassy pellicle over the surface of some Mediterranean colonial ascidians during the summer. In the present study, a similar non-feeding form was observed in the blue population in June 2003. Although the maximal water temperatures were reached 2 mo later (August), during June the seawater temperature increased by $6^{\circ} \mathrm{C}$, representing the most significant increase recorded during the study, which may have provoked the resting stage. However, no equivalent state was found in the purple population on the same dates.
Morgan (1977) observed that contact with other organisms inhibited growth of the colonial ascidians Botrylloides nigrum (Styelidae) and Aplidium lobatum (Polyclinidae). Subsequently, Bak et al. (1981) observed the same phenomenon in Trididemnum solidum (Didemnidae) overgrowing dead and/or living corals. Stocker \& Underwood (1991) found that rates of sexual and asexual reproduction of Didemnum moseleyi (Didemnidae) were lower when specimens were found close to sponges. No relationship could be statistically assessed between the growth rates of the purple morph and the presence of contacts with the sponge Crambe crambe, a chemically defended species known to be a good space competitor (Turon et al. 1996, Becerro et al. 1997). Other colonial ascidians (e.g. Diplosoma spongiforme and Didemnum sp.) and calcareous sponges were occasionally observed overgrowing some colonies of both morphotypes and may have punctually influenced their growth. Further and more specific work will be necessary to assess the influence of nearby competitors on the life cycle and ecology of Cystodytes.

Although it is indisputable that analyses of life-cycle parameters can contribute to the establishment of species boundaries (Templeton 1989), the degree to which they reflect speciation phenomena may vary among groups. In colonial ascidians, important intraspecific differences in life-history parameters (genetically determined) have been described for Botryllus schlosseri (Grosberg 1988, Yund et al. 1997), while in other instances divergence in biological parameters support the existence of cryptic speciation (Degnan \& Levin 1995, Dalby 1997a, De Caralt et al. 2002). In our case, the 2 morphotypes studied featured significant differences in biological traits. There is a lag in the reproductive periods that is maintained even in sympatric populations (e.g. the Medes Islands) and between years. Indeed, the larval release of one morphotype occurred almost exclusively after the release of the other morphotype was over.

Studies of morphological and ecological varieties of ascidians have often revealed genetic differentiation, suggesting that formerly recognized species should be split (Aron \& Solé-Cava 1991, Degnan \& Levin 1995, Tarjuelo et al. 2001, Turon et al. 2003). In some cases, color varieties have been shown to correspond to different species (Dalby 1997a,b, Tarjuelo et al. 2004), but not in others (Sabbadin 1982). The overwhelming message from molecular studies is that sibling and cryptic speciation phenomena are much more abundant in marine species than previously thought (Knowlton 2000). In our case, biological differences match previously reported genetic and chemical divergence between the 2 morphotypes analyzed. Detailed studies of phylogeography and gene flow among these mor- 
photypes should be performed to establish whether this is an instance of intraspecies variability or of sibling speciation. Given the variety of color morphs of Cystodytes found in other areas as well (e.g. Australia, Kott 1990), it seems that a thorough revision of the genus is necessary.

Acknowledgements. Dr. C. Palacín, Dr. F. Tomás, P. LópezSendino and A. Marí helped with the sampling. O. Sacristà and J. Spat helped with the laboratory work. This study was funded by Grant CTM2004-05265 from the Spanish Government and by the Interreg IIIA No. I3A-1-72-E program of the EU.

\section{LITERATURE CITED}

Aron S, Solé-Cava AM (1991) Genetic evaluation of the taxonomic status of two varieties of the cosmopolitan ascidian Botryllus niger (Ascidiaceae: Botryllidae). Biochem Syst Ecol 19:271-276

Ayling AM (1983) Growth and regeneration rates in thinly encrusting Demospongiae from temperate waters. Biol Bull (Woods Hole) 165:343-352

Bak RPM, Sybesma J, van Duyl FC (1981) The ecology of the tropical compound ascidian Trididemnum solidum. II. Abundance, growth and survival. Mar Ecol Prog Ser 6: 43-52

Becerro MA, Turon X, Uriz MJ (1995) Natural variation of toxicity in encrusting sponge Crambe crambe (Schmidt) in relation to size and environment. J Chem Ecol 21:1931-1946

Becerro MA, Uriz MJ, Turon X (1997) Chemically-mediated interactions in benthic organisms: the chemical ecology of Crambe crambe (Porifera, Poecilosclerida). Hydrobiologia 356:77-89

Berrill NJ (1935) Differential retardation and acceleration on studies in Tunicate development. Phil Trans R Soc Lond B 225:255-326

Brunetti R (1976) Biological cycle of Botrylloides leachi (Savigny) (Ascidiacea) in the Venetian lagoon. Vie Milieu 26:105-122

Brunetti R (1994) Ascidians of the northern Adriatic Sea. Aplousobranchia I. Boll Zool 61:89-96

Brunetti R, Copello M (1978) Growth and senescence in colonies of Botryllus schlosseri (Pallas) (Ascidiacea). Boll Zool 45:359-364

Brunetti R, Bressan M, Marin M, Libralato M (1988) On the ecology and biology of Diplosoma listerianum (Milne Edwards, 1841) (Ascidiacea, Didemnidae). Vie Milieu 38: 123-131

Caswell H (1982) Optimal life histories and the maximization of reproductive value: a general theorem for complex life cycles. Ecology 63(5):1218-1222

Caswell H (1985) The evolutionary demography of clonal reproduction. In: Jackson JBC, Buss LW, Cook EE (eds) Population biology and evolution of clonal organisms. Yale University Press, New Haven, CT, p 187-224

Coma R, Ribes M (2003) Seasonal energetic constraints if Mediterranean benthic suspension feeders: effects at different levels of ecological organization. Oikos 101: 205-215

Coma R, Ribes M, Gili JM, Zabala M (2000) Seasonality in coastal benthic ecosystems. Trends Ecol Evol 15:448-453

Dalby JE Jr (1997a) Reproductive and electrophoretic evidence for genetic maintenance of dimorphism in the ascidians Pyura stolonifera near Melbourne, Australia. Ophelia 47:227-243

Dalby JE Jr (1997b) Dimorphism in the ascidian Pyura stolonifera near Melbourne, Australia, and its evaluation through field transplant experiments. PSZN I: Mar Ecol $18: 253-271$

De Caralt S, López-Legentil S, Tarjuelo I, Uriz MJ, Turon X (2002) Contrasting biological traits of Clavelina lepadiformis (Ascidiacea) populations from inside and outside harbours in the western Mediterranean. Mar Ecol Prog Ser 244:125-137

Degnan BM, Levin MF (1995) Highly repetitive DNA sequences provide evidence for a lack of gene flow between two morphological forms of Herdmania momus (Ascidiacea: Stolidobranchia). Mar Biol 124:293-299

Durante KM, Sebens KP (1994) Reproductive ecology of the ascidians Molgula citrina Alder \& Hancock and Aplidium glabrum (Verrill, 1871) from the Gulf of Maine, USA. Ophelia 39:1-21

Forbes VE (2002) Resource allocation in asexual invertebrates. In: Adiyodi KG, Adiyodi RG, Hughes RN (eds) Reproductive biology of invertebrates, Vol XI. Progress in asexual reproduction. John Wiley \& Sons, Chichester, p 175-205

Fox GA (1993) Failure-time analysis: emergence, flowering, survivorship, and other waiting times. In: Scheiner SM, Gurevitch J (eds) Design and analysis of ecological experiments. Chapman \& Hall, London, p 113-137

Garrabou J, Zabala M (2001) Growth dynamics in four Mediterranean demosponges. Estuar Coast Shelf Sci 52: 293-303

Grosberg RK (1988) Life-history variation within a population of the colonial ascidian Botryllus schlosseri. I. The genetic and environmental control of seasonal variation. Evolution 42:900-920

Harper JL, Rosen BR, White J (eds) (1986) The growth and form of modular organisms. Phil Trans R Soc Lond B 313: $1-250$

Hughes RN (2002) Genetic mosaics and chimeras. In: Adiyodi KG, Adiyodi RG, Hughes RN (eds) Reproductive biology of invertebrates, Vol XI. Progress in asexual reproduction. John Wiley \& Sons, Chichester, p 159-173

Hughes RN, Cancino JM (1985) An ecological overview of cloning in Metazoa. In: Jackson JBC, Buss LW, Cook EE (eds) Population biology and evolution of clonal organisms. Yale University Press, New Haven, CT, p 153-186

Jackson JBC, Coates AG (1986) Life cycles and evolution of clonal (modular) animals. Phil Trans R Soc Lond B 313: $7-22$

Jackson JBC, Buss LW, Cook EE (eds) (1985) Population biology and evolution of clonal organisms. Yale University Press, New Haven, CT

Karlson RH (2002) Population processes in modular benthic invertebrates. In: Adiyodi KG, Adiyodi RG, Hughes RN (eds) Reproductive biology of invertebrates, Vol XI. Progress in asexual reproduction. John Wiley \& Sons, Chichester, p 256-282

Knowlton N (2000) Molecular genetic analyses of species boundaries in the sea. Hydrobiologia 420:73-90

Kott P (1990) The Australian Ascidiacea. Part 2. Aplousobranchia (1). Mem Queensl Mus 29(1):1-266

Krebs CJ (1989) Ecological methodology. Harper Collins Publishers, New York

Larwood G, Rosen BR (eds) (1979) Biology and systematics of colonial animals. Academic Press, London

López-Legentil S, Turon X (2005) How do morphotypes and 
chemotypes relate to genotypes? The colonial ascidian Cystodytes (Ascidiacea: Polycitoridae). Zool Scr 34:3-14 López-Legentil S, Dieckmann R, Bontemps-Subielos N, Turon X, Banaigs B (in press) Qualitative variation of alkaloids in color morphs of Cystodytes (Ascidiacea). Biochem Syst Ecol

Manly FJ (2001) Randomization and Monte Carlo methods in biology. Chapman \& Hall, London

Méliane I (2002) Contribution to the knowledge of the ascidian fauna in the south east of Tunis. MS thesis, University of Alicante, Spain

Millar RH (1952) The annual growth and reproductive cycle in four ascidians. J Mar Biol Assoc UK 31:41-46

Millar RH (1971) The biology of ascidians. Adv Mar Biol 9: $1-100$

Millar RH (1974) A note on the breeding season of three ascidians on coral reefs at Galeta in the Caribbean Sea. Mar Biol 23:127-129

Molin E, Gabriele M, Brunetti R (2003) Further news on hard substrate communities of the northern Adriatic Sea with data on growth and reproduction in Polycitor adriaticus (Von Drasche, 1883). Boll Mus Civ Stor Nat Venezia 54: $19-28$

Morgan TO (1977) Growth rate, age at sexual maturity, longevity, and seasonality in three West Indian colonial ascidians. PhD thesis, University of Puerto Rico, Mayagüez

Mukai H, Watanabe H (1974) On the occurrence of colony specificity in some compound ascidians. Biol Bull (Woods Hole) 147:411-421

Newlon AW III, Yund PO, Steward-Savage J (2003) Phenotypic plasticity of reproductive effort in a colonial ascidian Botryllus schlosseri. J Exp Zool 297:180-188

Okamura B, Freeland JR, Hatton-Ellis T (2002) Clones and metapopulations. In: Adiyodi KG, Adiyodi RG, Hughes RN (eds) Reproductive biology of invertebrates, Vol XI Progress in asexual reproduction. John Wiley \& Sons, Chichester, p 283-312

Osman RW (1977) The establishment and development of a marine epifaunal community. Ecol Monogr 47:37-63

Pérès JM (1958) Origine et affinités du peuplement en ascidies de la Méditerranée. Rapp P-V Reun Cons Int Explor Mer 14:493-502

Ryland JS, Wigley RA, Muirhead A (1984) Ecology and colonial dynamics of some Pacific reef flat Didemnidae (Ascidiacea). Zool J Linn Soc 80:261-282

Sabbadin (1982) Formal genetics of ascidians. Am Zool 22: $765-773$

Sebens KP (1982) Competition for space: growth rate, reproductive output, and escape in size. Am Nat 120:189-197

Sebens KP (1986) Spatial relationships among encrusting marine organisms in the New England subtidal zone. Ecol Monogr 56:73-96

Sebens KP (1987) The ecology of indeterminate growth in animals. Annu Rev Ecol Syst 18:371-407

Stocker LJ (1991) Effects of size and shape of colony on rates of fission, fusion, growth and mortality in a subtidal invertebrate. J Exp Mar Biol Ecol 149:161-175

Stocker LJ, Underwood AJ (1991) The relationship between the presence of neighbours and rates of sexual and

Editorial responsibility: Otto Kinne (Editor-in-Chief), Oldendorf/Luhe, Germany asexual reproduction in a colonial invertebrate. J Exp Mar Biol Ecol 149:191-205

Sutherland JP, Karlton RH (1977) Development and stability of the fouling community at Beaufort, North Carolina. Ecol Monogr 47:425-446

Tanaka K (2002) Growth dynamics and mortality of the intertidal encrusting sponge Halichondria okadai (Demospongiae, Halichondrida). Mar Biol 140:383-389

Tarjuelo I (2001) Reproductive strategies in colonial ascidians: relationships with other life-history traits and genetic structure. PhD thesis, University of Barcelona, Spain

Tarjuelo I, Turon X (2004) Resource allocation in ascidians: reproductive investment vs. other life-history traits. Invertebr Biol 123:168-180

Tarjuelo I, Posada D, Crandall KA, Pascual M, Turon X (2001) Cryptic species of Clavelina (Ascidiacea) in two different habitats: harbours and rocky littoral zones in the northwestern Mediterranean. Mar Biol 139:455-462

Tarjuelo I, Posada D, Krandall KA, Pascual M, Turon X (2004) Phylogeography, selection and speciation of color morphs in the colonial ascidian Pseudodistoma crucigaster. Mol Ecol 13:3125-3136

Templeton AR (1989) The meaning of species and speciation: a genetic perspective. In: Otte D, Endler JA (eds) Speciation and its consequences. Sinauer, Sunderland, MA, p 3-27

Todd CD, Turner SJ (1988) Ecology of intertidal and sublittoral cryptic epifaunal assemblages. II. Nonlethal overgrowth of encrusting bryozoans by colonial ascidians. J Exp Mar Biol Ecol 115:113-126

Turon X (1987) Estudio de las ascidias de las costas de Cataluña e Islas Baleares. PhD thesis, University of Barcelona

Turon X (1988) The ascidians of Tossa de Mar (NE Spain). II. Biological cycles of the colonial species. Cah Biol Mar 29: 407-418

Turon X (1992) Periods of non-feeding in Polysyncraton lacazei (Ascidiacea: Didemnidae): a rejuvenative process? Mar Biol 112:647-655

Turon X, Becerro MA (1992) Growth and survival of several ascidian species from the northwestern Mediterranean. Mar Ecol Prog Ser 82:235-247

Turon X, Becerro MA, Uriz MJ, Llopis J (1996) Small-scale association measures in epibenthic communities as a clue for allelochemical interactions. Oecologia 108:351-360

Turon X, Tarjuelo I, Uriz MJ (1998) Growth dynamics and mortality of the encrusting sponge Crambe crambe (Poecilosclerida) in contrasting habitats: correlation with population structure and investment in defence. Funct Ecol 12: $631-639$

Turon X, Tarjuelo I, Duran S, Pascual M (2003) Characterizing invasion processes with genetic data: an Atlantic clade of Clavelina lepadiformis (Ascidiacea) introduced into Mediterranean harbours. Hydrobiologia 503:29-35

Williams GC (1986) Retrospect on modular organisms. Phil Trans R Soc B 313:245-247

Yund PO, Marcum Y, Stewart-Savage J (1997) Life-history variation in a colonial ascidian: broad-sense heritabilities and tradeoffs in allocation to asexual growth and male and female reproduction. Biol Bull (Woods Hole) 192:290-299

Submitted: November 8, 2004; Accepted: March 12, 2005

Proofs received from author(s): June 24, 2005 